\title{
Effects of activating GABAB1 receptor on proliferation, migration, invasion and epithelial-mesenchymal transition of ovarian cancer cells
}

\author{
Jun Gao ${ }^{1+}$, Yao Gao ${ }^{2+}$, Shixin Lin², Xia Zou', Yukai Zhu², Xintong Chen², Hong Wan ${ }^{1 *}$ (D) and Hong Zhu ${ }^{1 *}$ (1)
}

\begin{abstract}
Objective: This study aimed to explore the effects of activating GABAB1 receptor by baclofen on proliferation, migration, invasion and epithelial-mesenchymal transition (EMT) of ovarian cancer cells.

Results: One hundred $\mu \mathrm{mol} / \mathrm{L}, 200 \mu \mathrm{mol} / \mathrm{L}$ and $300 \mu \mathrm{mol} / \mathrm{L}$ were selected as low, medium and high baclofen concentrations respectively. Cells were divided into four groups: Control, $100 \mu \mathrm{mol} / \mathrm{L}, 200 \mu \mathrm{mol} / \mathrm{L}$ and $300 \mu \mathrm{mol} / \mathrm{L}$. Compared with the control group, the viability, colony formation, migration and invasion of SKOV3 cells were inhibited, and the apoptosis of SKOV3 cells were enhanced significantly at $200 \mu \mathrm{mol} / \mathrm{L}$ and $300 \mathrm{\mu mol} / \mathrm{L}$ baclofen. Moreover, they changed significantly with the increase of baclofen concentration. Compared with the control group, the expression of E-cadherin and GABAB1 increased and the N-cadherin expression decreased significantly in $200 \mu \mathrm{mol} / \mathrm{L}$ and $300 \mu \mathrm{mol} / \mathrm{L}$ groups. Higher concentration of baclofen induced higher expression of E-cadherin and lower expression of $\mathrm{N}$-cadherin.

Conclusion: Baclofen inhibited the proliferation, cloning, migration, invasion and EMT of ovarian cancer cells by activating GABAB1 receptor. These results might contribute a lot to clarify the role and possible mechanism of GABAB1 receptor in ovarian cancer.
\end{abstract}

Keywords: GABAB1 receptor, Ovarian cancer, Epithelial-mesenchymal transition, Baclofen, G protein-coupled receptor

\section{Background}

Ovarian cancer is the third most common malignant tumor in female reproductive system, and it has the highest mortality rate among gynecological tumors [1]. Ovarian cancer is featured with hidden onset, difficulty in early detection, high degree of malignancy and easy recurrence and metastasis [1]. Ovarian cancer not only

\footnotetext{
*Correspondence: wanhong19777@163.com; zhuhong2424@163.com †Jun Gao and Yao Gao contributed equally to this work. 'Department of Obstetrics and Gynecology, the Third Affiliated Hospital of Nanchang University, Xiangshanbei Road 128, Donghu District, Nanchang 330008, Jiangxi, China

Full list of author information is available at the end of the article
}

seriously harms the patients' psychological and physical health, but also imposes a heavy financial burden on the patients and society.

Epithelial tumors are the most common among all primary ovarian cancer, accounting for about $50-70 \%$ [2]. Due to the low response rate to drug therapy and poor prognosis, the mortality rate of epithelial ovarian cancer is still high [3-5]. Intensive study of epithelial ovarian cancer is of great economic and social significance for the early detection and treatment of ovarian cancer. The development and progression of ovarian cancer is a multi-factor and complex process, where multi-gene and

C C The Author(s). 2020 Open Access This article is licensed under a Creative Commons Attribution 4.0 International License, which permits use, sharing, adaptation, distribution and reproduction in any medium or format, as long as you give appropriate credit to the original author(s) and the source, provide a link to the Creative Commons licence, and indicate if changes were made. The images or other third party material in this article are included in the article's Creative Commons licence, unless indicated otherwise in a credit line to the material. If material is not included in the article's Creative Commons licence and your intended use is not permitted by statutory regulation or exceeds the permitted use, you will need to obtain permission directly from the copyright holder. To view a copy of this licence, visit http://creativecommons.org/licenses/by/4.0/ The Creative Commons Public Domain Dedication waiver (http://creativecommons.org/publicdomain/zero/1.0/) applies to the data made available in this article, unless otherwise stated in a credit line to the data. 
multi-signal pathways are involved. Its specific pathogenesis has not yet been fully understood. However, the proliferation, migration and epithelial-mesenchymal transition (EMT) of tumor cells are undoubtedly important factors for the development and invasion of epithelial ovarian cancer [6].

G protein-coupled receptor (GPCR) is considered to be a successful source of drug targets. The targets of over $50 \%$ of clinical drugs and drugs under development are GPCRs, and nine Nobel Prizes have been awarded for the important discoveries in the field of GPCR [7]. $\gamma$-aminobutyric acid (GABA) is an inhibitory neurotransmitter and it is the main neurotransmitter in the central nervous system. It plays a crucial role in regulating the excitability of nerve cells [8]. The execution of GABA function is inseparable from its unique receptor system. Receptors of GABA include ionic receptors such as GABAA and GABAC and metabolic receptor GABAB [9]. GABAB receptor regulates downstream activities through $\mathrm{G}$ protein coupling, such as inhibiting adenylate cyclase, activating potassium channels, and inhibiting voltage-dependent calcium channels, and it also play an important role in the development process [10-12]. Neurotransmitters are found to play an important role in the regulation of tumor cells through affecting the growth and development of tumors [13]. GABA inhibits the growth of lung cancer cells through GABAB receptor [14]. For patients with ovarian cancer, increased levels of GABA in urine represent a worsening of the cancer [15]. The expression of GABAB receptor may be closely related to the growth of cancer cells. As a member of the GPCR family, GABAB1 receptor participates in many important physiological activities such as the generation of learning and memory and the transmission of synaptic signals. The overactivation or inhibition of GABAB1 receptor will cause various neurological disorders [16]. GABA is a natural ligand of GABAB1 receptor and GABAB1 is the most active subtype of GABAB [9]. Naumenko et al. report in 2017 that baclofen has two stable coupling sites with GABAB1, which is a specific agonist of GABAB1 receptor [17].

Therefore, in this study, we aimed to explore the effects of activating GABAB1 receptor by baclofen on the proliferation, migration, invasion and EMT of SKOV3 cells, so as to clarify the role and possible mechanism of GABAB1 receptor in ovarian cancer. Human ovarian cancer cell line SKOV3 was taken as the research object for its extensive use as a model cell line in ovarian cancer research. This study might provide a theoretical basis for the further development of anti-cancer drugs coupled with GABAB1 receptor.

\section{Materials and methods}

\section{Materials and cells}

Baclofen (HY-B0007/CS-2990) was purchased from MedChemExpress (Monmouth Junction, NJ, USA).
CCK-8 kit was provided by Keygen Biotech (Jiangsu, China). Annexin V-fluorescein isothiocyanate (FITC)/ propidium iodide (PI) apoptosis kit was gotten from Multi Sciences (Zhejiang, China). Trizon Reagent, Ultrapure RNA extraction kit, HiFiScript cDNA synthesis kit and UltraSYBR Mixture were bought from CWBIO (Beijing, China). RIPA buffer was provided by Applygen (Beijing, China). Mouse anti-glyceraldehyde-3-phosphate dehydrogenase (GAPDH) monoclonal antibody (TA-08), peroxidase-conjugated goat anti-rabbit $\operatorname{IgG}(\mathrm{H}+\mathrm{L})$ (ZB$2301)$ and peroxidase-conjugated goat anti-mouse $\operatorname{IgG}(\mathrm{H}+\mathrm{L})(\mathrm{ZB}-2305)$ were obtained from ZSGB-BIO (Beijing, China). Rabbit anti-E-cadherin monoclonal antibody (ab407742), rabbit anti-N-cadherin polyclonal antibody (ab18203) and mouse anti-GABAB1 receptor monoclonal antibody (ab55051) were purchased from Abcam (Cambridge, MA, USA).

Human ovarian cancer cell line SKOV3 (BNCC310551) and human normal ovarian cell line IOSE80 (BNCC340318) were obtained from BeNa Culture Collection (Beijing, China). The cells were cultured in McCoy's 5A medium (Keygen Biotech, Jiangsu, China) containing $10 \%$ fetal bovine serum (Biological Industries, Kibbutz Beit Haemek, Israel) at $37^{\circ} \mathrm{C}$ and $5 \% \mathrm{CO}_{2}$.

\section{Screening of baclofen concentration}

SKOV3 Cells were seeded into 96-well plate at $1 \times 10^{4}$ cells per well. When cell confluence reached $70-80 \%$, culture media was changed to fetal bovine serum-free media. The cells were cultured for $24 \mathrm{~h}$ and incubated with baclofen at different concentrations $(50 \mu \mathrm{mol} / \mathrm{L}$, $100 \mu \mathrm{mol} / \mathrm{L}, 200 \mu \mathrm{mol} / \mathrm{L}, 400 \mu \mathrm{mol} / \mathrm{L}$ and $800 \mu \mathrm{mol} / \mathrm{L})$ for another $24 \mathrm{~h}$. After adding $10 \mu \mathrm{l}$ CCK8 reagent, the cells were cultured for another $2 \mathrm{~h}$. Eventually, absorbance was measured at $450 \mathrm{~nm}$ on a microplate reader (RT-6100, Rayto, USA). Cell viability was calculated accordingly.

\section{Experimental grouping}

Cells were divided into four groups: Control, $100 \mu \mathrm{mol} /$ $\mathrm{L}, 200 \mu \mathrm{mol} / \mathrm{L}$ and $300 \mu \mathrm{mol} / \mathrm{L}$. For $100 \mu \mathrm{mol} / \mathrm{L}$ group, $200 \mu \mathrm{mol} / \mathrm{L}$ group and $300 \mu \mathrm{mol} / \mathrm{L}$ group, cells were incubated with baclofen at $100 \mu \mathrm{mol} / \mathrm{L}, 200 \mu \mathrm{mol} / \mathrm{L}$ and $300 \mu \mathrm{mol} / \mathrm{L}$, respectively, for $24 \mathrm{~h}$.

\section{Cell viability}

IOSE80 cells and SKOV3 cells were seeded into 96-well plate at $1 \times 10^{4}$ cells per well. When cell confluence reached $70-80 \%$, the culture media was replaced by fetal bovine serum-free media. The cells were cultured for 24 $\mathrm{h}$ and then incubated with baclofen for $24 \mathrm{~h}$ according to the above experimental grouping. Finally, the cells were examined by CCK8 assay as indicated above. 


\section{Cell apoptosis}

IOSE80 cells and SKOV3 cells were incubated with baclofen for $24 \mathrm{~h}$ according to the above experimental grouping and then treated with Annexin V-FITC/PI apoptosis kit according to the manufacturer's manual. In brief, $1 \times 10^{6}-3 \times 10^{6}$ cells were collected and resuspended in $300 \mu \mathrm{L} 1 \times$ binding buffer. Cell suspension was then mixed with $3 \mu \mathrm{L}$ Annexin V-FITC and $5 \mu \mathrm{L}$ PI at room temperature for $10 \mathrm{~min}$ in the dark. After adding $200 \mu \mathrm{L} 1 \times$ binding buffer, the cells were examined immediately using a flow cytometer (NovoCyte 2060R, Acea Biosciences, China).

\section{Cell colony formation}

SKOV3 cells were exposed to baclofen according to the above experimental grouping. The cells were then collected and seeded into 6-well plate at 300 cells per well. After culturing for 10 days, the cells were fixed in $4 \%$ paraformaldehyde for $15 \mathrm{~min}$, washed three times with phosphate buffer saline (PBS), stained in $0.1 \%$ crystal violet for $45 \mathrm{~min}$, washed three times with $\mathrm{PBS}$ again and microscopically examined.

\section{Cell migration}

SKOV3 cells were exposed to baclofen according to the above experimental grouping. The cells were collected and seeded into 24-well plate. When cell confluence reached $90 \%$, a scratch was made using a $10 \mu$ l pipette tip across the cell monolayer. Subsequently, the cells were washed three times with PBS. Fetal bovine serumfree media was added and the scratch was microscopically examined. After culturing for $24 \mathrm{~h}$, the cells were visualized again using a microscope.

\section{Cell invasion}

Matrigel was coated onto the membranelle of transwell inserts and cultured at $37^{\circ} \mathrm{C}$. SKOV3 cells were exposed to baclofen according to the above experimental grouping, collected and resuspended in fetal bovine serumfree media. Cell concentrations were adjusted to $1 \times 10^{5}$ cells per $\mathrm{ml}$. Cell suspension $(300 \mu \mathrm{l})$ and complete media $(500 \mu \mathrm{l})$ were added into upper and lower chambers, respectively. Transwell inserts were cultured for 24 h. The cells were washed with PBS for $5 \mathrm{~min}$ and stained in $0.1 \%$ crystal violet for $60 \mathrm{~min}$. The cells in the upper chamber were removed using cotton swabs. The cells in the lower chamber were examined microscopically and counted.

\section{Expression of E-cadherin, N-cadherin and GABAB1 determined by RT-PCR}

SKOV3 cells were exposed to baclofen according to the above experimental grouping. Total RNA was extracted using Trizon reagent and Ultrapure RNA extraction kit according to the manufacturer's instructions. Reversed transcription of RNA to cDNA was performed using HiFiScript cDNA synthesis kit according to the manufacturer's instruction. Primers were shown in Table 1 and added into a $25 \mu \mathrm{l}$ PCR system which was composed of $1 \mu \mathrm{l}$ cDNA/DNA, $1 \mu \mathrm{l}$ forward primer, $1 \mu \mathrm{l}$ reverse primer, $12.5 \mu \mathrm{l}$ ULtraSYBR Mixture and $9.5 \mu \mathrm{l}$ RNase free $\mathrm{dH}_{2} \mathrm{O}$ ). Reaction parameters included pre-denaturation for $10 \mathrm{~min}$ at $95^{\circ} \mathrm{C}$, denaturation for $10 \mathrm{~s}$ at $95^{\circ} \mathrm{C}$, annealing for $30 \mathrm{~s}$ at $50^{\circ} \mathrm{C}$, elongation for $30 \mathrm{~s}$ at $72^{\circ} \mathrm{C}$, and 40 circles. Analysis parameters of dissociation curve included $15 \mathrm{~s}$ at $95^{\circ} \mathrm{C}, 1 \mathrm{~min}$ at $50^{\circ} \mathrm{C}, 15 \mathrm{~s}$ at $95^{\circ} \mathrm{C}, 15 \mathrm{~s}$ at $50^{\circ} \mathrm{C}, 15 \mathrm{~s}$ at $50^{\circ} \mathrm{C}$, and measured stepwise from $95^{\circ} \mathrm{C}$, every $0.5^{\circ} \mathrm{C}$. Finally, PCR product was examined on a RT-PCR machine (CFX Connect, Bio-Rad, USA). GAPD $\mathrm{H}$ served as an internal control.

\section{Expression of E-cadherin, N-cadherin and GABAB1 determined by Western blot}

SKOV3 cells were exposed to baclofen according to the above experimental grouping and lysed in RIPA buffer for $30 \mathrm{~min}$. Cell lysate was centrifuged at $12000 \mathrm{rpm}$ and $4{ }^{\circ} \mathrm{C}$ for $10 \mathrm{~min}$. The supernatant was collected carefully to acquire total protein. Protein concentration was examined using a BCA kit. Subsequently, the proteins were denatured and loaded to conduct SDS-PAGE electrophoresis for $1-2 \mathrm{~h}$. The proteins were transferred to membranes by a wet method for 30-90 min. The membranes were incubated in primary antibody buffer overnight at $4{ }^{\circ} \mathrm{C}$, washed, and incubated in secondary antibody buffer for $1-2 \mathrm{~h}$ at room temperature. After adding chemiluminescence solution, the membranes were evaluated on a gel imaging system (ChemiDoc XRS+, Bio-Rad, USA). Relative amounts of protein per band were measured with Image Lab 5.2 software (BioRad, USA).

\section{Statistical analysis}

Every experiment was repeated five times. SPSS 19.0 software was used to carry out statistical analysis which was based on analysis of variance (ANOVA) followed by a post hoc test. Difference was considered to be significant at $P<0.05$.

\section{Results}

\section{Screening of baclofen concentration}

The viability of SKOV3 cells after incubation with different concentrations of baclofen $(50 \mu \mathrm{mol} / \mathrm{L}, 100 \mu \mathrm{mol} / \mathrm{L}$, $200 \mu \mathrm{mol} / \mathrm{L}, 400 \mu \mathrm{mol} / \mathrm{L}$ and $800 \mu \mathrm{mol} / \mathrm{L}$ ) was shown in Fig. 1a. When the baclofen concentration reached $200 \mu \mathrm{mol} / \mathrm{L}$, the cell viability decreased significantly compared with the control $(P<0.05)$. Cell viability decreased significantly with increasing concentration of baclofen $(P<0.05)$, but $400 \mu \mathrm{mol} / \mathrm{L}$ and $800 \mu \mathrm{mol} / \mathrm{L}$ 
Table 1 Primers for RT-PCR

\begin{tabular}{|c|c|c|c|}
\hline Gene & Primer $\left(5^{\prime}-3^{\prime}\right)$ & Length of primer (bp) & Length of product (bp) \\
\hline \multirow[t]{2}{*}{ E-cadherin } & For: CTCACATTTCCCAACTCCTCT & 21 & 234 \\
\hline & Rev: TGTCACCTTCAGCCATCCT & 19 & \\
\hline \multirow[t]{2}{*}{$\mathrm{N}$-cadherin } & For: GCTTATCCTTGTGCTGATGTTT & 22 & 142 \\
\hline & Rev: GTCTTCTTCTCCTCCACCTTCT & 22 & \\
\hline \multirow[t]{2}{*}{ GABAB1 } & For: GTGAATAGCCGCAGGGACA & 19 & 215 \\
\hline & Rev: CTGGAGCCATAGGAAAGCA & 19 & \\
\hline \multirow[t]{2}{*}{ GAPDH } & For: GAAGGTCGGAGTCAACGGAT & 20 & 224 \\
\hline & Rev: CCTGGAAGATGGTGATGGG & 19 & \\
\hline
\end{tabular}

baclofen caused similar cell viability. Therefore, the following experiments were carried out at $100 \mu \mathrm{mol} / \mathrm{L}$, $200 \mu \mathrm{mol} / \mathrm{L}$ and $300 \mu \mathrm{mol} / \mathrm{L}$ as low, medium and high concentrations of baclofen respectively.

\section{Cell viability}

The viability of SKOV3 cells and IOSE80 cells in various groups was shown in Fig. 1b. There was similar viability of SKOV3 cells between the control and $100 \mu \mathrm{mol} / \mathrm{L}$ groups. Compared with the control and $100 \mu \mathrm{mol} / \mathrm{L}$ groups, the viability of SKOV3 cells decreased sharply when $200 \mu \mathrm{mol} / \mathrm{L}$ and $300 \mu \mathrm{mol} / \mathrm{L}$ baclofen was exerted $(P<0.05)$. However, compared with the control group, there was no significant difference in the viability of IOSE80 cells when treated with 100, 200 and $300 \mu \mathrm{mol} /$ $\mathrm{L}$ baclofen. It was suggested that baclofen only reduced the viability of ovarian cancer cells, but not normal ovarian cells.

\section{Cell apoptosis}

The apoptosis of SKOV3 cells and IOSE80 cells in various groups was shown in Fig. 2. There was similar apoptosis of SKOV3 cells between the control and $100 \mu \mathrm{mol} /$ $\mathrm{L}$ groups. The apoptotic rates of SKOV3 cells increased significantly with increasing concentration of baclofen $(P<0.05)$. However, compared with the control group, there was no significant difference in the apoptosis of IOSE80 cells when treated with 100, 200 and $300 \mu \mathrm{mol} /$ $\mathrm{L}$ baclofen. These results suggested that baclofen only reduced the viability and enhanced the apoptosis of ovarian cancer cells, but not normal ovarian cells. Therefore, the following experiments were only performed in SKOV3 cells.

\section{Cell colony formation}

The colony formation of SKOV3 cells in various groups was shown in Fig. 3a. Compared with the control group, the cell numbers were reduced remarkably when $100 \mu \mathrm{mol} / \mathrm{L}, 200 \mu \mathrm{mol} / \mathrm{L}$ and $300 \mu \mathrm{mol} / \mathrm{L}$ baclofen was used $(P<0.05)$. Moreover, the cell numbers decreased significantly with increasing concentration of baclofen $(P<0.05)$.

\section{Cell migration}

The cell scratches and mobility rates of SKOV3 cells in various groups were shown in Fig. 3b. Compared with the control group, $100 \mu \mathrm{mol} / \mathrm{L}, \quad 200 \mu \mathrm{mol} / \mathrm{L}$ and $300 \mu \mathrm{mol} / \mathrm{L}$ baclofen significantly reduced the cell mobility rate $(P<0.05)$. Moreover, the mobility rate decreased significantly with the increase of baclofen concentration $(P<0.05)$.

\section{Cell invasion}

The numbers of SKOV3 cells in the lower chamber of transwell assay in various groups were shown in Fig. 3c. There were similar cell numbers between the control and $100 \mu \mathrm{mol} / \mathrm{L}$ groups. Compared with the control group, $200 \mu \mathrm{mol} / \mathrm{L}$ and $300 \mu \mathrm{mol} / \mathrm{L}$ baclofen significantly reduced the cell numbers in the lower chamber $(P<$ $0.05)$. Moreover, the cell numbers in the lower chamber decreased significantly with the increase of baclofen concentration $(P<0.05)$.

\section{Expression of E-cadherin, N-cadherin and GABAB1}

Figure 4 showed the mRNA and protein levels of Ecadherin, N-cadherin and GABAB1 in various groups which were examined by RT-PCR and western blot, respectively. Compared with the control group, the expression of E-cadherin and GABAB1 increased significantly and the expression of N-cadherin decreased significantly in $200 \mu \mathrm{mol} / \mathrm{L}$ and $300 \mu \mathrm{mol} / \mathrm{L}$ groups $(P<$ 0.05). Higher concentration of baclofen induced higher expression of E-cadherin and lower expression of $\mathrm{N}$ cadherin $(P<0.05)$.

\section{Discussion}

It is generally believed that the development and progression of ovarian cancer are related to the activation of proto-oncogenes and inactivation of tumor suppressor genes. The proliferation, migration and EMT of tumor cells are important characteristics for the development 


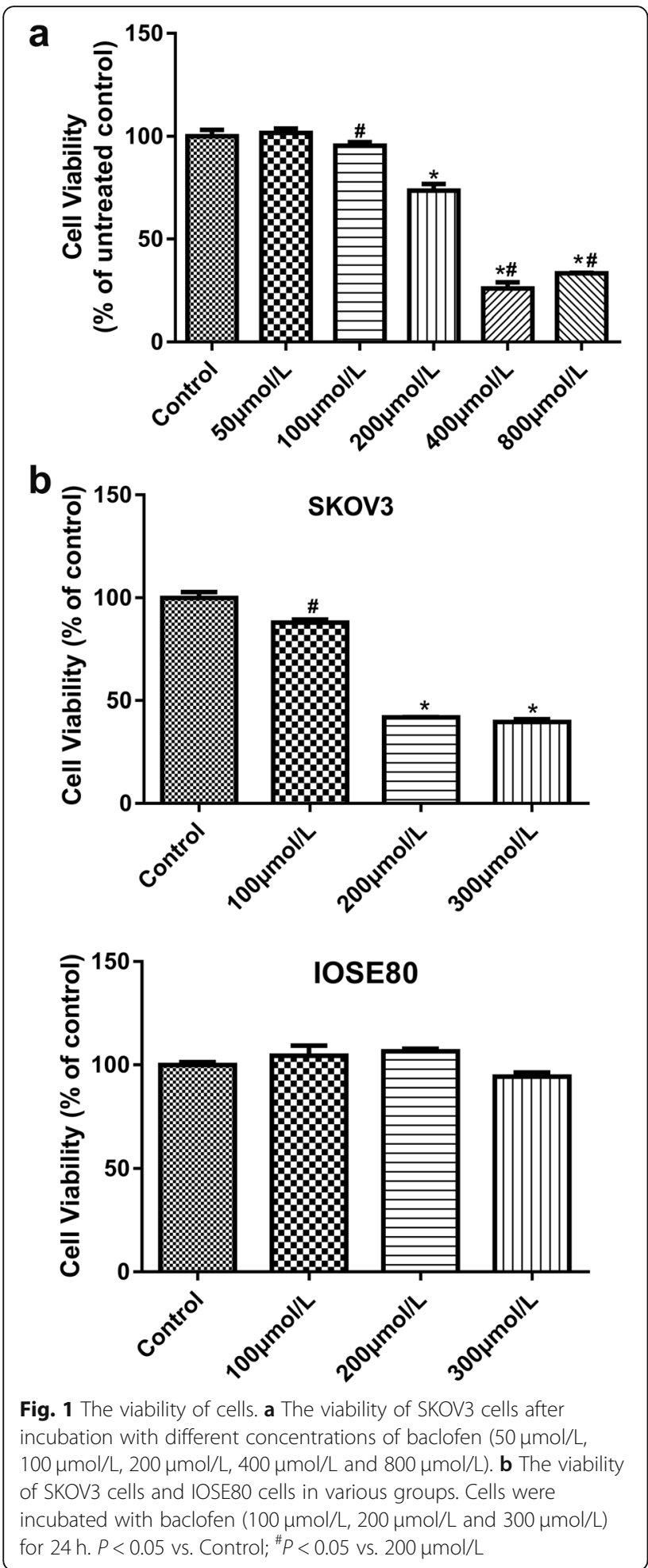

and invasion of ovarian cancer [18]. Neurotransmitters are important proteins which widely exist in the central and peripheral nervous systems and they mediate neurophysiological activities of the body. GABA is the main neurotransmitter in the central nervous system and plays an important role in regulating the excitability of nerve cells [19]. The execution of GABA function depends on its unique receptor system. Hypofunction of GABA receptor system will cause epilepsy, spasm, anxiety, stress, sleep disorder, depression, addiction and pain, while excessive activation of GABA receptor will cause schizophrenia [20].

GABAB1 receptor is widely expressed in a variety of cancer tissues and cancer cells, which are closely related to the development of various cancers such as lung cancer, colon cancer, pancreatic cancer and liver cancer [2124]. GABAB1 receptor plays a negative regulatory role in the migration of cancer cells and can also inhibit the development and progression of tumors [21-24]. Baclofen is a derivative of GABA, which can inhibit the release of excitatory amino acid, reduce the excitability of monosynaptic and polysynaptic reflexes in the spinal cord, and reduce the substance $P$ release and calcium influx, thereby alleviating myotonia and painful spasm [25]. Therefore, baclofen is a specific activator of GABAB1 [26]. In this study, we revealed that the mRNA level of GABAB1 was significantly increased when the concentration of Baclofen reached $200 \mu \mathrm{mol} / \mathrm{L}$ and $300 \mu \mathrm{mol} / \mathrm{L}$, while its protein level was significantly elevated when the baclofen concentration was $100 \mu \mathrm{mol} / \mathrm{L}, 200 \mu \mathrm{mol} / \mathrm{L}$ and $300 \mu \mathrm{mol} / \mathrm{L}$. This agreed with a previous report [26]. These results suggested that baclofen could up-regulate the expression of GABAB1 and activate GABAB1.

Moreover, baclofen can inhibit the proliferation and migration of human hepatocellular carcinoma cells, lung cancer cells, gastrointestinal cancer, breast cancer and pancreatic ductal cancer cells [27-30]. This study also showed that the proliferation and migration of epithelial ovarian cancer cell line SKOV3 were significantly decreased and the cloning and invasive ability of SKOV3 cells were inhibited by baclofen at a certain concentration. Besides, baclofen at a certain concentration could enhance the apoptosis of SKOV3 cells. These results might indicate that baclofen activated GABAB1 receptor, consequently inhibiting the proliferation, cloning, migration and invasion of ovarian cancer cells and promoting the apoptosis of ovarian cancer cells.

EMT refers to the process of epithelial cells transforming into mesenchymal cells phenotype under certain conditions. Decrease of intercellular adhesion force, disappearance of the cells polarity, change of the cytoskeleton, enhancement of the ability of epithelial cells to deform, migrate and move, loss of the epithelial markers and acquirement of interstitial markers are found during this process [31]. Different types of EMT play different roles in different biological processes such as fertilized egg implantation, embryogenesis, organ development, tissue regeneration, fibrosis of epithelial tissues, invasion and metastasis of tumors [32]. EMT significantly affects the development and progression of tumors [33]. N- 


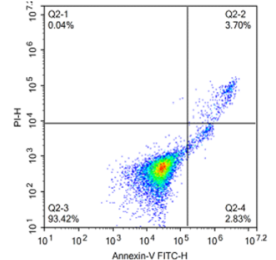

Control

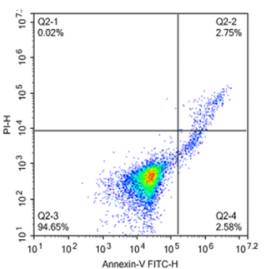

$200 \mu \mathrm{mol} / \mathrm{L}$

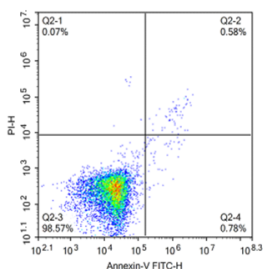

Control

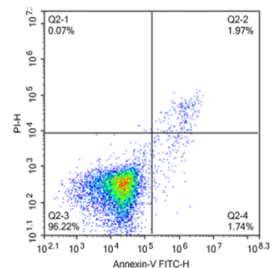

$200 \mu \mathrm{mol} / \mathrm{L}$

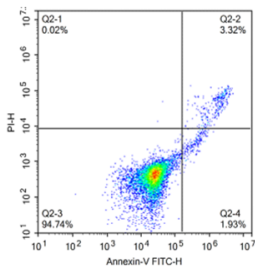

$100 \mu \mathrm{mol} / \mathrm{L}$

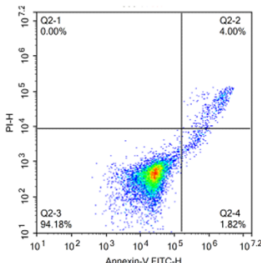

$300 \mu \mathrm{mol} / \mathrm{L}$

a

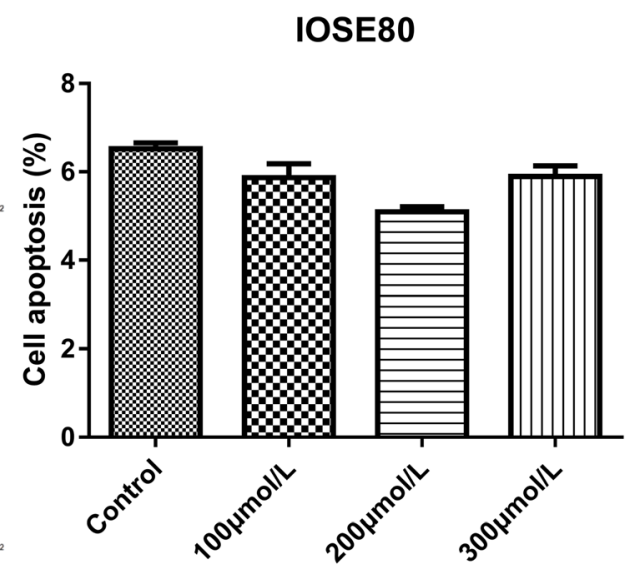

b

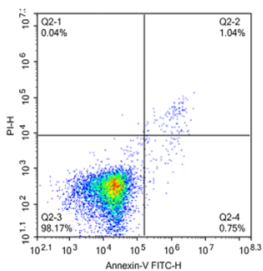
$100 \mu \mathrm{mol} / \mathrm{L}$
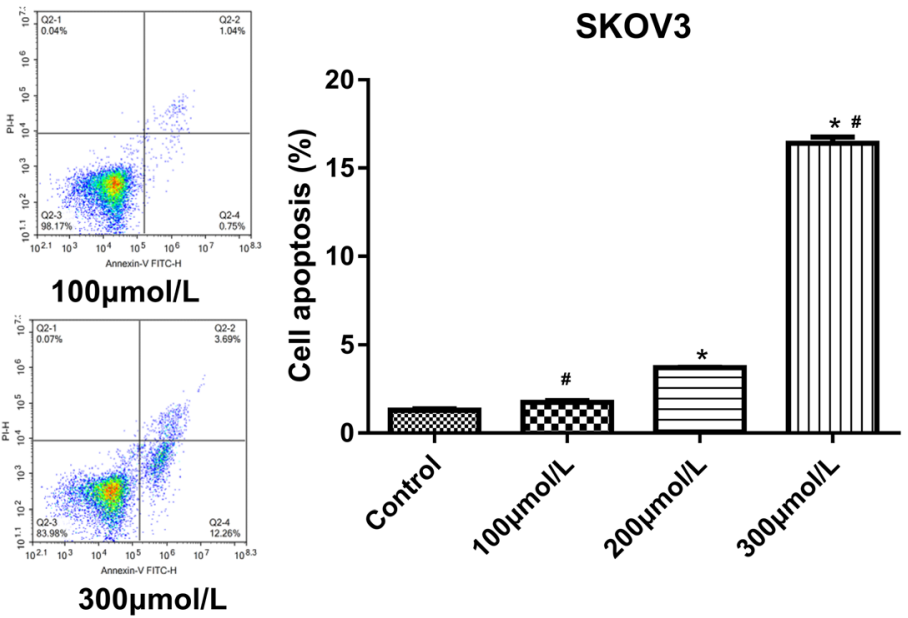

Fig. 2 The apoptosis of IOSE80 cells (a) and SKOV3 cells (b) in various groups. Cells were incubated with baclofen $(100 \mu \mathrm{mol} / \mathrm{L}, 200 \mu \mathrm{mol} / \mathrm{L}$ and $300 \mu \mathrm{mol} / \mathrm{L}$ ) for 24 h. $P<0.05$ vs. Control; ${ }^{\#} P<0.05$ vs. $200 \mu \mathrm{mol} / \mathrm{L}$

cadherin and E-cadherin are the focused genes in the investigation of EMT. E-cadherin is an important molecule of intercellular junction. The expression of E-cadherin is down-regulated during the EMT process, resulting in the decrease of intercellular adhesion force, while the up-regulation of N-cadherin expression is another important marker of EMT [34]. This study showed that when ovarian cancer cells were exposed to baclofen, Ecadherin expression increased significantly and $\mathrm{N}$ cadherin expression decreased significantly. It was suggested that baclofen could inhibit the EMT of ovarian cancer cells.

Evaluating the influence of Baclofen incubation at different times on the SKOV3 cell line can enhance the rigor of this study. The time point of $24 \mathrm{~h}$ in this study was selected according to a previous report that Zhang et al. examined the role of GABA signaling molecule in breast cancer metastasis based on $24 \mathrm{~h}$ treatment time of baclofen [29]. Moreover, in this study, the inhibition rate of $400 \mu \mathrm{mol} / \mathrm{L}$ baclofen on cell proliferation exceeded $50 \%$ at $24 \mathrm{~h}$, so the $24 \mathrm{~h}$ treatment time was chosen and no other time points were evaluated. GABAB1 and GABAB2 are the two most common subtypes of GABA $B$ receptors and are often studied together. For example, we previously revealed that Pinocembrin inhibited the proliferation and migration of ovarian cancer cells and promoted their apoptosis by down-regulating the mRNA levels of GABAB1 and GABAB2 [35]. However, another study reported that the expression of GABAB1 in SKOV3 cells was higher than that of GABAB2, indicating that GABAB1 might be more active in SKOV3 cells [36]. Therefore, GABAB1 receptor was examined in this study. Nevertheless, the absence of GABAB2 receptor analysis was also a shortcoming of this study. In our 


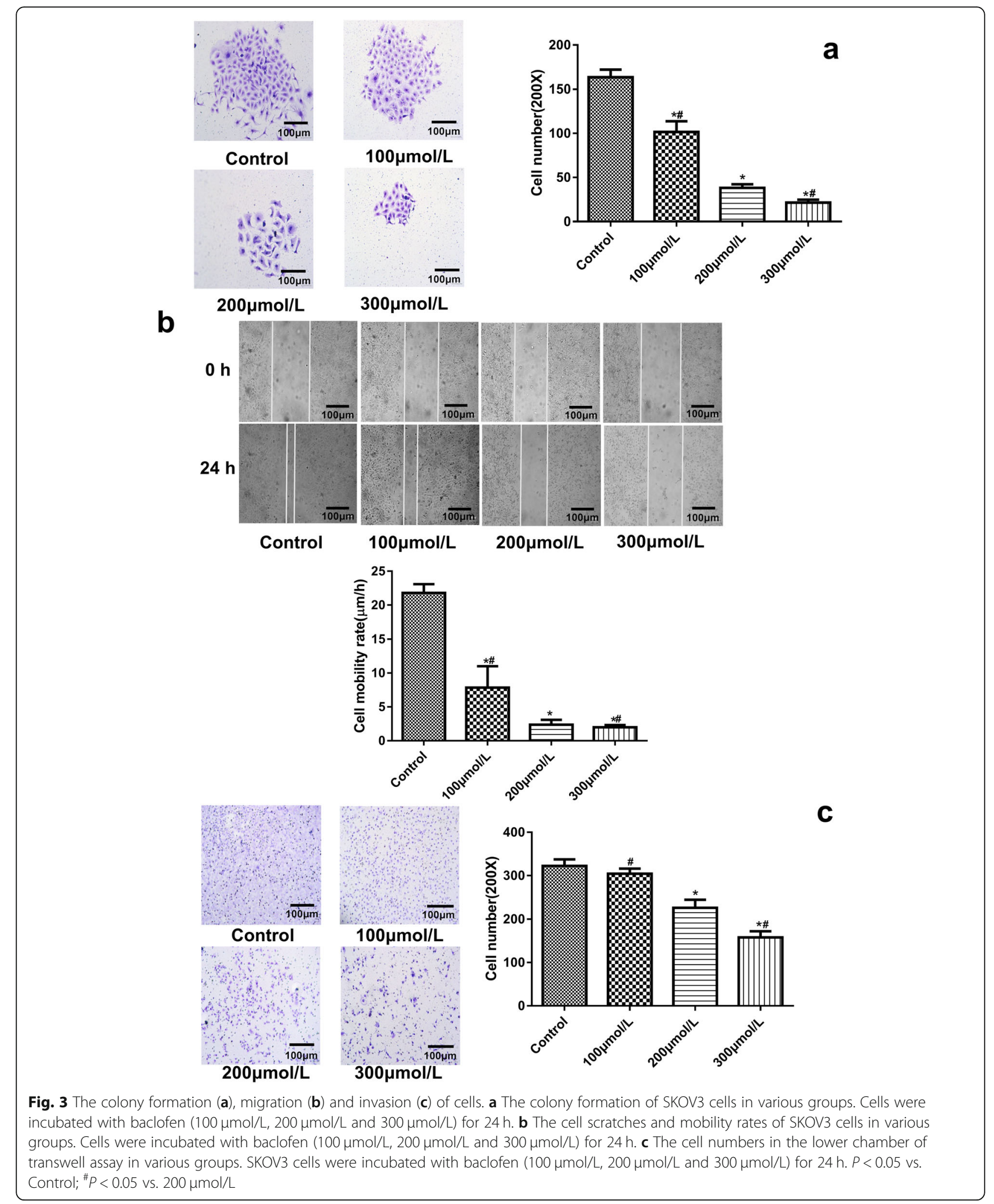

further in-depth study, we would conduct necessary analysis of GABAB2. More cell lines can better prove the effect of baclofen on ovarian cancer cells, but SKOV3 is a commonly used cell line for studying ovarian adenocarcinoma. Paramee et al. only used SKOV3 cells to investigate the effect of Kaempferia parviflora on ovarian 


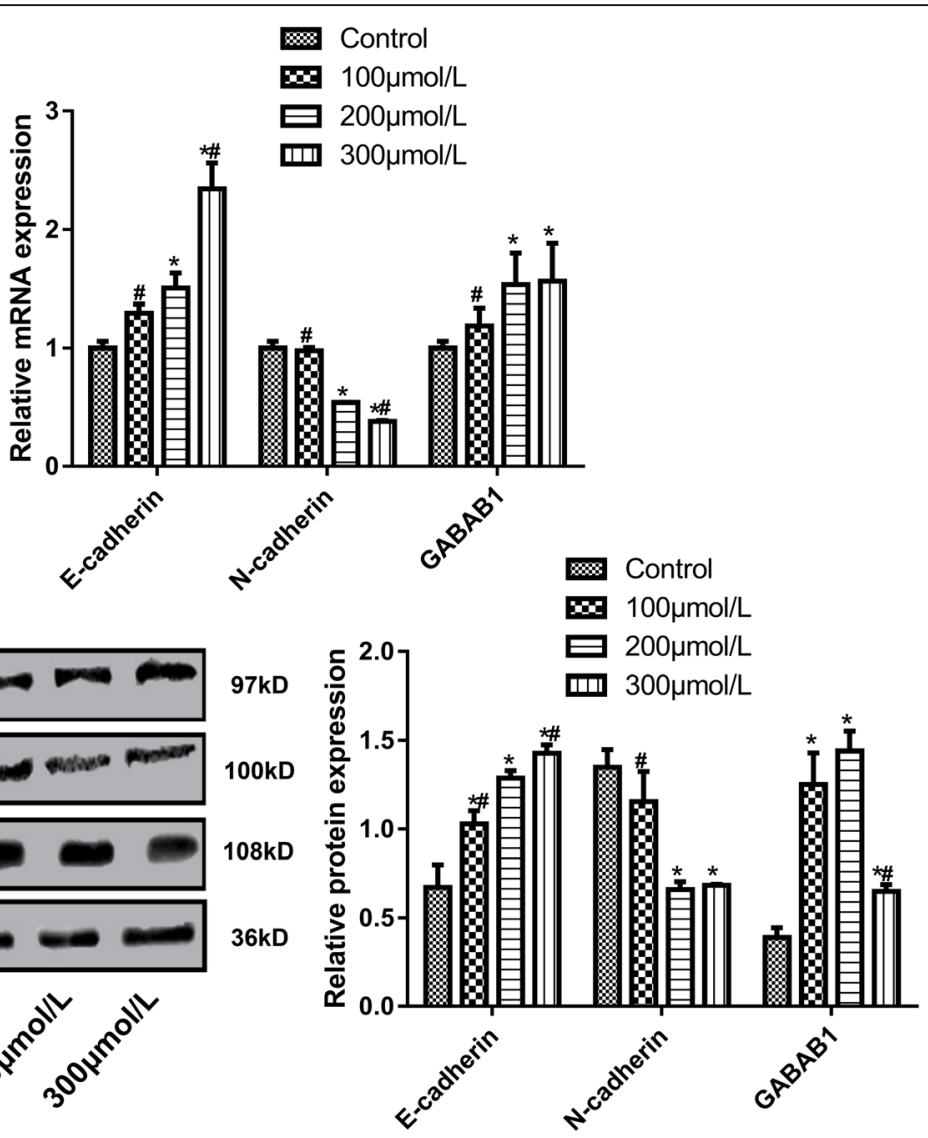

Fig. 4 The mRNA and protein levels of E-cadherin, N-cadherin and GABAB1 in various groups which were examined by RT-PCR and western blot, respectively. SKOV3 cells were incubated with baclofen $(100 \mu \mathrm{mol} / \mathrm{L}, 200 \mu \mathrm{mol} / \mathrm{L}$ and $300 \mu \mathrm{mol} / \mathrm{L})$ for $24 \mathrm{~h} . P<0.05$ vs. Control; ${ }^{\#} P<0.05$ vs. $200 \mu \mathrm{mol} / \mathrm{L}$

cancer and it was concluded that Kaempferia parviflora inhibited the proliferation, migration and invasion and induced apoptosis of ovarian cancer cells [37]. Zhao et al. also only chose SKOV3 cells to explore the combination therapies of dihydroartemisinin and curcumin for ovarian cancer [38]. Moreover, we had previously proved that Pinocembrin could down-regulate the mRNA levels of Ncadherin and GABAB receptor in SKOV3 cells and thereby inhibit the proliferation and migration of ovarian cancer cells [35]. Nevertheless, the absence of more ovarian cancer cell lines was a limitation of this study. We would conduct a further in-depth investigation in more ovarian cancer cell lines and animal model.

\section{Conclusion}

Baclofen inhibited the proliferation, cloning, migration, invasion and EMT of ovarian cancer cells by activating GABAB1 receptor. This might contribute a lot to clarify the role and possible mechanism of GABAB1 receptor in ovarian cancer and might provide a theoretical basis for the further development of anti-cancer drugs coupled with GABAB1 receptor.

\section{Abbreviations}

ANOVA: Analysis of variance; EMT: Epithelial-mesenchymal transition; FITC: Fluorescein isothiocyanate; GABA: $\gamma$-aminobutyric acid; GAPD H: Glyceraldehyde-3-phosphate dehydrogenase; GPCR: G protein-coupled receptor; PBS: Phosphate buffer saline; PI: Propidium iodide

\section{Acknowledgements}

The authors thank the reviewers for their helpful on this article.

Authors' contributions

J.G. and Y. G. carried out experimental work, conducted the statistical analysis and wrote the manuscript. S.L., X.Z., Y.Z. and X.C. took part in experimental work, collected data and helped with data analysis. H.W. and H.Z. designed experiments, interpreted the data and revised the manuscript. All authors read and approved the manuscript.

\section{Funding}

This work was supported by the Science and Technology Project of Health Commission of Jiangxi Province (Grant No. 20175032), the Traditional

Chinese Medicine Project of Health Commission of Jiangxi Province (Grant No. 2016B032), the Key R\&D Program of Jiangxi Province (Grant No. 20181BBG70034), the Health Capacity Project of Nanchang City (Grant No. 2017JS001) and the Science and Technology Project of the First Hospital of Nanchang.

Availability of data and materials

All data generated or analysed during this study are included in this published article. 


\section{Ethics approval and consent to participate}

This article is a cell experiment, so it does not involve Human Participants and/or Animal.

\section{Consent for publication}

Not applicable.

\section{Competing interests}

The authors declare that they have no competing interests.

\section{Author details}

'Department of Obstetrics and Gynecology, the Third Affiliated Hospital of Nanchang University, Xiangshanbei Road 128, Donghu District, Nanchang 330008, Jiangxi, China. ${ }^{2}$ Postgraduate Department, Jiangxi Medical College of Nanchang University, Nanchang 330008, Jiangxi, China.

Received: 24 July 2020 Accepted: 5 October 2020

Published online: 24 October 2020

\section{References}

1. Ginestra A, Miceli D, Dolo V, et al. Membrane vesicles in ovarian cancer fluids: a new potential marker. Anticancer Res. 2016;19:3439-45.

2. Zhang H, Liu T, Zhang Z, et al. Integrated Proteogenomic characterization of human high-grade serous ovarian Cancer. Cell. 2016;166:755-65.

3. Takano M, Kikuchi Y, Yaegashi N, et al. Clear cell carcinoma of the ovary: a retrospective multicentre experience of 254 patients with complete surgical staging. Br J Cancer. 2006;94:1369-74.

4. Kobayashi H, Yamada Y, Kanayama S, et al. The role of hepatocyte nuclear factor-1beta in the pathogenesis of clear cell carcinoma of the ovary. Int J Gynecol Cancer. 2009;19:471-9.

5. Jemal A, Tiwari RC, Murray T, et al. Cancer statistics, 2004. CA Cancer J Clin. 2004;54:8-29.

6. Antoniou AC, Pharoah PDP, Narod S, et al. Breast and ovarian cancer risks to carriers of the BRCA1 5382insC and 185delAG and BRCA2 6174delT mutations: a combined analysis of 22 population based studies. J Med Genet. 2016;42:602-3.

7. Ziarek JJ, Kleist AB, London N, et al. Structural basis for chemokine recognition by a $\mathrm{G}$ protein-coupled receptor and implications for receptor activation. Sci Signal. 2017;10:eaah5756.

8. Sheng $L$, Shen D, Luo $Y$, et al. Exogenous $Y$-aminobutyric acid treatment affects citrate and amino acid accumulation to improve fruit quality and storage performance of postharvest citrus fruit. Food Chem. 2017;216:138-45.

9. Wang Y, Gu W, Meng Y, et al. Y-Aminobutyric Acid Imparts Partial Protection from Salt Stress Injury to Maize Seedlings by Improving Photosynthesis and Upregulating Osmoprotectants and Antioxidants. Sci Rep. 2017:7:43609.

10. Hyland NP, Cryan JF. A gut feeling about GABA: focus on GABA(B) receptors. Front Pharmacol. 2010;1:124.

11. Chen $\mathrm{K}, \mathrm{Li} H Z$, Ye N, et al. Role of GABAB receptors in GABA and baclofeninduced inhibition of adult rat cerebellar interpositus nucleus neurons in vitro. Brain Res Bull. 2005:67:310-8.

12. Geng $Y$, Bush M, Mosyak $L$, et al. Structural mechanism of ligand activation in human GABA(B) receptor. Nature. 2013:504:254-9.

13. Entschladen F, Drell TL 4th, Lang K, et al. Neurotransmitters and chemokines regulate tumor cell migration: potential for a new pharmacological approach to inhibit invasion and metastasis development. Curr Pharm Des. 2005;11:403-11.

14. Schuller HM, Al-Wadei HA, Majidi M. Gamma-aminobutyric acid, a potential tumor suppressor for small airway-derived lung adenocarcinoma. Carcinogenesis. 2008;29:1979-85.

15. Nicholson-Guthrie CS, Guthrie GD, Sutton GP, et al. Urine GABA levels in ovarian cancer patients: elevated GABA in malignancy. Cancer Lett. 2001; 162:27-30

16. Grewal J, Khare SK. 2-Pyrrolidone synthesis from y-aminobutyric acid produced by Lactobacillus brevis under solid-state fermentation utilizing toxic deoiled cottonseed cake. Bioprocess Biosyst Eng. 2017:40:145-52.

17. Naumenko AM, Shapoval LM, Nyporko AY, et al. Computer simulation of molecular interaction between baclofen and the GABA B receptor. Neurophysiology. 2017:49:2-7.
18. Clark CA, Gupta HB, Sareddy G, et al. Tumor-intrinsic PD-L1 signals regulate cell growth, pathogenesis, and autophagy in ovarian Cancer and melanoma. Cancer Res. 2017;76:6964-74.

19. Scholz SS, Malabarba J, Reichelt M, et al. Evidence for GABA-induced systemic GABA accumulation in Arabidopsis upon wounding. Front Plant Sci. 2017:8:388.

20. Ren $\mathrm{W}$, Yin J, Xiao $\mathrm{H}$, et al. Intestinal microbiota-derived GABA mediates Interleukin-17 expression during Enterotoxigenic Escherichia coli infection. Front Immunol. 2017:7:685.

21. Li H, Zhang A, Hao Y, et al. Coexistence of Lambert-Eaton myasthenic syndrome and autoimmune encephalitis with anti-CRMP5/CV2 and antiGABAB1 receptor antibodies in small cell lung cancer: a case report. Medicine 2018:97:e0696.

22. Shu Q, Liu J, Liu X, et al. GABAB R/GSK-3//NF-KB signaling pathway regulates the proliferation of colorectal cancer cells. Cancer Med. 2016;5: 1259-67.

23. Schuller HM. Regulatory role of $\mathrm{G}$ protein-coupled receptors in pancreatic cancer development and progression. Curr Med Chem. 2018;25:2566-75.

24. Khalilov I, Minlebaev M, Mukhtarov M, et al. Postsynaptic GABA(B) receptors contribute to the termination of Giant depolarizing potentials in CA3 neonatal rat hippocampus. Front Cell Neurosci. 2017;11:179.

25. Delaney AJ, Crane JW, Holmes NM, et al. Baclofen acts in the central amygdala to reduce synaptic transmission and impair context fear conditioning. Sci Rep. 2018;8:9908.

26. Pitman KA, Borgland SL, Macleod B, et al. Isovaline does not activate GABA(B) receptor-coupled potassium currents in GABA(B) expressing AtT-20 cells and cultured rat hippocampal neurons. PLoS One. 2015;10:e0118497.

27. Santana L, Quintero M. F725 avoidance of life-threatening baclofen withdrawal. Eur J Pain Suppl. 2012;5:195.

28. Sharma C, Acharya M, Kumawat BL, et al. 'Dancing eyes, dancing feet syndrome' in small cell lung carcinoma. BMJ Case Rep. 2014;2014.

29. Zhang D, Li X, Yao Z, et al. GABAergic signaling facilitates breast cancer metastasis by promoting ERK 1/2 -dependent phosphorylation. Cancer Lett. 2014;348:100-8

30. Banerjee J, Alwadei MH, Alwadei HAN, et al. Abstract 2191: GABA but not baclofen prevents gemcitabine resistance induced by low dose nicotine in pancreatic cancer xenografts. Cancer Res. 2013:73:2191.

31. Chen T, You Y, Jiang H, et al. Epithelial-Mesenchymal transition (EMT): a biological process in the development, stem cell differentiation and tumorigenesis. J Cell Physiol. 2017;232:3261-72.

32. Zhou P, Li B, Liu F, et al. The epithelial to mesenchymal transition (EMT) and cancer stem cells: implication for treatment resistance in pancreatic cancer. Mol Cancer. 2017;16:52.

33. Noman MZ, Janji B, Abdou A, et al. The immune checkpoint ligand PD-L1 is upregulated in EMT-activated human breast cancer cells by a mechanism involving ZEB-1 and miR-200. Oncoimmunology. 2017:6:e1263412.

34. Chen L, Muñozantonia T, Cress WD. Trim28 contributes to EMT via regulation of $\mathrm{E}$-cadherin and $\mathrm{N}$-cadherin in lung Cancer cell lines. PLoS One. 2014;9:e101040

35. Gao J, Lin S, Gao Y, et al. Pinocembrin inhibits the proliferation and migration and promotes the apoptosis of ovarian cancer cells through down-regulating the mRNA levels of $\mathrm{N}$-cadherin and GABAB receptor. Biomed Pharmacother. 2019:120:109505.

36. Söderhielm PC, Klein AB, Bomholtz SH, et al. Profiling of GABAA and GABAB receptor expression in the myometrium of the human uterus. Life Sci. 2018; 214:145-52

37. Paramee $S$, Sookkhee $S$, Sakonwasun $C$, et al. Anti-cancer effects of Kaempferia parviflora on ovarian cancer SKOV3 cells. BMC Complement Altern Med. 2018:18:178.

38. Zhao J, Pan Y, Li X, et al. Dihydroartemisinin and Curcumin synergistically induce apoptosis in SKOV3 cells via Upregulation of MiR-124 targeting Midkine. Cell Physiol Biochem. 2017:43:589-601.

\section{Publisher's Note}

Springer Nature remains neutral with regard to jurisdictional claims in published maps and institutional affiliations. 